\title{
Variability in the diet diversity of catfish highlighted through DNA barcoding
}

Chinnamani Prasannakumar ${ }^{1,2 *}$, Gunasekaran Iyyapparajanarasimapallavan ${ }^{3,4}$, M. Ashiq Ur Rahman $^{5}$, P. Mohanchander ${ }^{6}$, T. Sudhakar ${ }^{7}$, K. Kadharsha ${ }^{8}$, K. Feroz Khan ${ }^{9}$, J. Vijaylaxmi ${ }^{10}$, Narra Prasanthi ${ }^{11}$, Kumaran Subramanian ${ }^{12}$ and Seerangan Manokaran ${ }^{13}$

${ }^{1}$ Biological Oceanography Division, CSIR-National Institute of Oceanography, Dona Paula, Panaji, Goa-403 004, India.

${ }^{2}$ Institute of Marine Microbes and Ecosphere, State Key Laboratory for Marine Environmental Sciences, Xiamen University, Xiamen, Fujian, 361 102, China.

${ }^{3}$ Department of Fisheries Laboratory, Tamil Nadu Fisheries Department, Chetpet Ecopark Campus, Kilpauk, Chennai - 600010

${ }^{4}$ Marine Biotechnology Division, Central Marine Fisheries Research Institute, Ernakulam North P.O., Kochi - 682018

${ }^{5}$ Department of Zoology, Hajee Karutha Rowther Howdia College, Uthamapalayam, Theni District, Tamil Nadu- 625 533, India

${ }^{6}$ Department of Zoology, Madras Christian College, East Tambaram, Chennai, Tamil Nadu600 059, India

${ }^{7}$ Department of Zoology, Kavitha's college of arts and science, Vaiyappamalai, Trinchangode, Tamil Nadu- 637 410, India

${ }^{8}$ PG \& Research Department of Zoology, C. Abdul Hakeem College, Melvisharam, Vellore, Tamil Nadu- 632 509, India

${ }^{9}$ Research Department of Microbiology, Sadakathullah Appa College, Rahmath Nagar, Tirunelveli Tamil Nadu -627011, India

${ }^{10}$ Department of Marine Sciences, Goa University, Taleigao Plateau, Goa-403206, India

${ }^{11}$ Centre of Advance studies in Marine Biology, Parangipettai, Tamil Nadu-608502, India

${ }^{12}$ Centre for Drug Discovery and Development, Sathyabama Institute of Science and Technology, Tamil Nadu-600119, India

${ }^{13}$ Center for Environment \& Water, King Fahd University of Petroleum and Minerals, Dhahran-31261, Saudi Arabia

*Corresponding author’s email id.: micropras@gmail.com 


\begin{abstract}
Identification and quantification of fish diet diversity was the first step in understanding the food web dynamics and ecosystem energetics, where the contribution of DNA barcoding technique has been important. We used DNA barcoding to identify the stomach contents of a euryhaline, benthophagous catfish Ariius maculatus. From 40 catfish stomach items sampled in two different seasons, we barcoded 67 piscine and macroinvertebrates prey items, identified as belonging to 13 species in 4 major phyla (viz., Chordate, Arthropod, Annelida and Mollusca). It is important to note that the mollusc taxa (Meritrix meritrix and Perna viridis) and a species of fish (Stolephorus indicus) could not be found among the gut contents of A. maculatus sampled during the pre- and post-monsoon season, respectively. Among the piscine diets of A. maculatus, Eubleekeria splendens $(23.5 \%)$ and Stolephorus indicus $(23.5 \%)$ were the major prey taxa during pre-monsoon season. The hermit crabs forms the major constituents of both pre- and post-monsoon seasons, among invertebrate taxa. Polychaete, Capitella capitata $(25.92 \%)$ was abundantly consumed invertebrates next to hermit crabs. We noticed that in pre-monsoon A. maculatus was more piscivorous than post-monsoon. As revealed through Kimura-2 parametric pairwise distance analysis, the diet diversity was relatively higher in post-monsoon. The accumulation curve estimated 57 haplotypes within 14 barcoded species (including the host A. maculatus). Majority of haplotypes were found among fishes (47.36\%) followed by Arthropods (28.07\%), Annelids (14.03\%) and Mollusca (10.52\%), respectively. This study also highlights that there is a growing concern about A. maculatus's aggressive predation on commercially important stocks of fish and invertebrates. We will continue to expand the coverage of species barcoded in the reference database, which will become more significant as meta- and environmental DNA barcoding techniques become cheaper and prevalent.
\end{abstract}

Keywords: Arius maculatus, catfish, Stomach analysis, DNA barcoding, pairwise distance, diet diversity

\title{
1. Introduction
}

In Ichthyology, the first step towards identifying trophic levels of the fish species was the determination and quantification of fish stomach contents (Hynes, 1950; Hyslop, 1980; Cresson et al., 2014) and understanding of food web dynamics and energy of the ecosystem 
(Beauchamp et al. 2007). The traditional visual survey of stomach content, however, did not provide data to be compared across studies (Cortés, 1997; Hernández, 2019), as level of taxonomic resolution at which a prey was classified (e.g. order, family, genus or species level) and the metrics used for quantification (e.g. count, volume) differed between the studies (Berg, 1979; Hyslop, 1980; Hansson, 1998; Hernández, 2019). While much work has been expended in standardizing dietary analysis (Pinkas, 1971; Cortés, 1997), it has not been universally accepted as a standard technique (Baker et al., 2014). Prey items that is present at different digestive stages when analysing the gut produces ambiguity in taxonomic resolution and identification. These findings differ through studies and rely on different factors, such as the methodology adapted for prey identification, prey condition, prior taxonomic knowledge of the prey species, and the objective of the gut analysis (example: Elliott, 1967; Baker and Sheaves, 2005; Saunders et al., 2012; Gray et al., 2015). In addition to complications due to unreported prey assumption, variable taxonomic resolutions compound the inconsistency and make the findings incomparable between studies.

DNA barcoding refers to sequencing the standard barcode region and matching them with archived sequences derived from validated species to facilitate species identification (Hebert et al., 2003; Joly et al., 2014; Kress et al., 2015). DNA barcoding has been used to study trophic dynamics (Valdez-Moreno et al. 2012; Wirta et al. 2014; Moran et al. 2015), environmental forensics (Dalton and Kotze 2011; Handy et al. 2011; Gonçalves et al. 2015), cryptic diversity and invasive species identification (Hebert et al. 2004; Conway et al. 2014; Bariche et al. 2015), ecosystem and evolutionary diversity evaluation (Ward et al. 2005; Baldwin et al. 2011; Weigt et al. 2012a; Leray and Knowlton 2015) and phylogenetic exploration (Nagy et al. 2012; Baeza and Fuentes 2013; Betancur-Ret al. 2013). While a number of markers available (e.g., 16sRNA, 18sRNA, matK, rbcL, ITS), a 650 base pair (bp) region in the mitochondrial cytochrome c oxidase 1 (COI) gene is one of the most widely used in fish (and other animals) (Ward et al., 2005; Lakra et al., 2010; Khan et al., 2011; Weigt et al. 2012b). Species recognition is made by comparing the query sequence to that of archived sequences in reference databases, such as the Barcode of Life Database (BOLD) (Ratnasingham and Hebert 2007) using the BOLD-Identification System (BOLDIDs) and in GenBank (National Center for Biotechnology Information) using Basic Local Alignment Sequence Tool (BLAST) (Altschul et al. 1990). DNA barcoding has been widely applied in assessment of diversity and composition of fin and shell fishes (Teodoro et al., 2016; Sharawy et al., 2017; Zhang et al., 2017; Wang et al., 2017; Kuguru et al., 2018; Ran et al., 2020; Xu et al., 2021). DNA barcoding is currently commonly used in consumer markets 
to identify sharks and their products (Holmes et al., 2009; Nijman et al., 2015; Hellberg et al., 2019). DNA barcodes acts as a potential forensic tool to track illegally traded and mislabeled endangered fishery products (Pappalardo \& Ferrito, 2015; Di Pinto et al., 2015; Sembiring et al., 2015; Velez-Zuazo et al., 2015; Carvalho et al., 2017; Bunholi et al., 2018).

In recent years, the use of DNA barcoding to identify digested prey items has increased, especially in the identification of deepwater sharks prey items (Barnett et al. 2010; Dunn et al. 2010); Lake fish predators (Carreon-Martinez et al. 2011); invasive lionfish Pterois sp. (Valdez-Moreno et al. 2012; Cote et al. 2013; Rocha et al. 2015; Dahl et al., 2017; Ritger et al., 2020; Santamaria et al., 2020); groundfish (Paquin et al. 2014); pterygophagous (fin eating; Arroyave and Stiassny 2014) and lepidophagous (scale eating; Boileau et al. 2015) fishes; introduced largemouth Bass Micropterus salmoides (Jo et al. 2014); warmwater catfish (Moran et al. 2015); herbivorous juvenile Sandy Spinefoot Siganus fuscescens (Chelsky Budarf et al. 2011); gray seals Halichoerus grypus and harbor porpoises Phocoena phocoena (Méheust et al. 2015) and stranded Humboldt squid Dosidicus gigas (Braid et al. 2012). Nonetheless, few studies have investigated the effectiveness of DNA barcoding in relation to the digestive state of fish prey (Carreon-Martinez et al. 2011; Moran et al. 2015). Although few studies have successfully used DNA barcoding in the analysis of catfish piscine prey items of (Moran et al., 2015; Aguillar et al., 2016; Guillerault et al., 2017), studies are rare in elucidating both vertebrate and invertebrate prey content of benthophagous catfishes like Arius maculatus (Thunberg 1792). A. maculatus is a euryhaline, benthophagous species in tropical and sub-tropical waters, estuaries, rivers and coastal regions (Mazlan et al., 2008; Chu et al., 2011; Jumawan et al., 2020), whose economic importance and potential for aquaculture have recently been recognised (Jumawan et al., 2020). Commonly referred as spotted catfish (Chu et al., 2011), A. maculatus belongs to Ariidae family (Carpenter and Niem 1999), along with eight other species and is known for its pharmaceutical and nutraceutical values (Al-Bow et al., 1997; Osman et al., 2007). The present study aims to identify the species composition in the dietary items of A. maculatus occurring in the Vellar estuary (southeast coast of India).

The effectiveness of DNA barcoding for species identification largely depends on the establishment of broad and robust barcode reference databases of validated, verified species with vouchered specimens. A lack of vouchered or incorrectly identified sequences (Ekrem et al. 2007; Valdez-Moreno et al. 2012; Weigt et al. 2012a) would severely decrease the utility of reference databases. In addition, to capture potential genetic variation, including undocumented cryptic diversity, it is important to sequence an adequate number of 
individuals from across a species range (Weigt et al. 2012b). We have made considerable efforts in the past decade as part of the Indian Census of Marine Life (ICoML) to recover barcodes in reasonable numbers of marine phyla including fin \& shell fishes, invertebrates (Khan et al., 2010, 2011; PrasannaKumar et al., 2012; Thirumaraiselvi et al., 2015; Rajthilak et al., 2015; Rahman et al., 2013, 2019; Hemalatha et al., 2016; Palanisamy et al., 2020; PrasannaKumar et al., 2020a, b; Manikantan et al., 2020; Thangaraj et al., 2020) and plants (Sahu et al., 2016; Narra et al., 2020) occurring in and around the Vellar estuary. Hence we predict a high rate of success in identification of dietary items of A. maculatus occurring in this environment.

\section{Material and methods}

\subsection{Catfish collection and stomach analysis}

During April (pre-monsoon) and December (post-monsoon) 2011, catfish sampling was carried out in the Vellar estuary (latitude: $11^{\circ} 29^{\prime} \mathrm{N}$; longitude: $79^{\circ} 46^{\prime} \mathrm{E}$ ). Individuals were collected fresh from local fishery folks who used hand nets to fish regularly in Vellar estuary. A total of 40 catfishes were collected (18 in pre-monsoon; 22 in post-monsoon). Upon collection freshly captured fish were transported to DNA barcoding Lab, Centre of Advanced Study in Marine Biology, Annamalai University, within $1 \mathrm{~km}$ from collection site, in the saltwater ice slurry to slow down catfish digestion and prey DNA degradation (Baker et al., 2014). Each catfish has been measured (to nearest mm; total length (Lt)) and weighed (to nearest $0.1 \mathrm{~g})$.

After examination of the oesophagus and gills for prey, Catfish (Arius maculatus (Thunberg, 1792)) digestive tracts were removed. In order to remove digestive enzymes, excess chyme and particulate organic matter using $500 \mu \mathrm{m}$ sieves, the digestive tracks were dissected and their contents were rinsed with RO water. Recognisable prey taxa were divided into two classes, namely fish and invertebrates, and into 2 digestive stages, namely whole animals (i.e., most of the biomass was present) and digestive remnants (in bits and pieces). The remnants were rinsed once in $100 \%$ molecular grade ethanol (Sigma) and approximately $3 \mathrm{~mm}^{3}$ tissue plug was exercised under the $\sim 1 \mathrm{~mm}$ top tissue layer (especially in fish preys) from all recognisable prey items (examined under binocular microscope whenever necessary) to avoid sample contamination by A. maculatus cells (Cote et al., 2013). Once again, the tissues exercised were rinsed and stored in microfuge tubes (Thermo Fisher Scientific) containing $100 \%$ ethanol at $4^{\circ} \mathrm{C}$ until further analysis. Residual tissues in scalpel and forceps were removed with $95 \%$ ethanol and flame sterilized between each exercise. Samples of 
lateral tissue samples were also taken from A. maculatus for DNA barcoding because if cannibalism was alleged in the diet, it would provide useful reference (Valdez-Moreno et al., 2012).

\subsection{DNA extraction, $P C R$ and sequencing the dietary contents}

The DNA was extracted using the DNeasy Blood \& Tissue Kits (Qiagen), following the manufacturer's instructions or standard protocols (Prasannakumar et al., 2020). Tissue was placed in an extraction buffer containing proteinase $\mathrm{K}$ and homogenized with polypropylene disposable sterile pestles (Thermo Fisher Scientific). The homogeneous was digested at $56{ }^{\circ} \mathrm{C}$ until complete digestion of the sample (i.e, when most of the homogenate is more translucent) that was within 12 hours. Elution buffer was used as the negative control to test the purity of the reagents. The extracted DNA for quantification and purity estimation (i.e., using 260/280 $\mathrm{nm}$ ratio) was quantified using Nanodrop (Thermo Fisher Scientific). Elution buffer provided in the kit was used during Nanodrop measurements to calibrate the blank. Also, DNA concentration was checked in 1.2\% Agarose gels and the high DNA yields (>85 ng/ $\mu \mathrm{l})$ were 10X diluted before PCR in ultrapure water.

DNA from fish-like prey samples was PCR amplified using COI primers; FishF1 and FishR1 (Ward et al., 2005) and invertebrate samples were using LCO1490 and HCO2198 (Folmer et al., 1994). A reaction mixture volume of $25 \mu 1$ was used to conduct PCR; $12.5 \mu 1$ Taq PCR Master Mix (Invitrogen, India), $11 \mu$ l distilled water, $0.5 \mu l$ forward primer $(10 \mu \mathrm{M})$, $0.5 \mu \mathrm{l}$ reverse primer $(10 \mu \mathrm{M})$, and $0.5 \mu \mathrm{l}$ DNA template $(50-80 \mathrm{ng} / \mu \mathrm{l})$ were used. Initial steps of 2 min at $95{ }^{\circ} \mathrm{C}$, followed by 35 cycles of $30 \mathrm{~s}$ at $94{ }^{\circ} \mathrm{C}, 30 \mathrm{~s}$ at $54^{\circ} \mathrm{C}$, and $1 \mathrm{~min}$ at $72{ }^{\circ} \mathrm{C}$, followed by $10 \mathrm{~min}$ at $72{ }^{\circ} \mathrm{C}$ and kept at $4{ }^{\circ} \mathrm{C}$ were used for FishF1/FishR1 primer amplified samples. Initial denaturation for $2 \mathrm{~min}$ at $95^{\circ} \mathrm{C}$, followed by 5 cycles at $94{ }^{\circ} \mathrm{C}$ for $30 \mathrm{~s}, 46^{\circ} \mathrm{C}$ for $45 \mathrm{~s}, 72^{\circ} \mathrm{C}$ for $45 \mathrm{~s}$ and 35 cycles at $94{ }^{\circ} \mathrm{C}$ for $30 \mathrm{~s}, 51^{\circ} \mathrm{C}$ for $45 \mathrm{~s}, 72{ }^{\circ} \mathrm{C}$ for $45 \mathrm{~s}$, and a final elongation stage at $72{ }^{\circ} \mathrm{C}$ for $5 \mathrm{~min}$ were used for LCO1490/HCO2198 primers amplified samples. Positive and negative control were used each set of PCR sample runs. Ultrapure water, which replaces DNA templates, serves as a negative control and extracted DNA of A. maculatus was used as positive control. On $1.5 \%$ agarose gels, PCR products were visualized and positive reactions were verified by a clear band aligned parallel to $650 \mathrm{bp}$ of the Invitrogen $100 \mathrm{bp}$ DNA ladder (Thermo Fisher Scientific, MA) fragment. All positive PCR products were labelled with the acronym DADB1, DADB2,...DADB71, (Dietary Analysis using DNA Barcodes) ( $\mathrm{n}=71)$ alongside positive and negative control and were commercially sequenced bi-directionally with the sequencing primers M13F and M13R 
(Ivanova et al., 2007) and BigDye Terminator Cycle sequencing kit (Applied Biosystems) on an ABI 3730 capillary sequencer at Macrogen Inc. (South Korea).

\subsection{DNA sequence analysis}

Until at least every generated sequence was $>600 \mathrm{bp}$ in length, sequencing efforts were repeated. Forward and reverse sequences were trimmed using ChromasLite ver.2.1 to remove ambiguous and/or low quality bases and remnant primer from amplification or sequencing reactions. Sequences were compiled, and by translating DNA sequences into putative amino acid sequences in BioEdit ver. 7.9 (Hall, 1999) and aligned in Clustal X ver. 2.0.6 (Thompson, 1997), the gaps within the DNA sequences were tested. More than 600 bp length were all final contigs. The Barcode of Life Data Systems (BOLD) ID search engine (Ratnasingham and Hebert, 2007) and GenBank's BLAST tool (Altschul et al., 1990) have been used as a reference libraries to identify the barcode sequences generated. Molecular Evolutionary Genetic analysis (MEGA) ver. 4.1 (Kumar et al., 2018) using Kimura 2 parameters (K2P) (Kimura, 1980) was used to construct neighbour-joining (NJ) tree (Saitou et al., 1987). Bootstrap test (100 replicates) was used to test the reliability of the branches (Felsenstein, 1985). For tree based identification, sequences of statistically significant (highest query coverage (q) or lowest error (e) values) references were extracted from GenBank. For better representation of tree based identification, the NJ tree was redrawn using the Interactive Tree Of Life (iTOL) (Letunic and Bork, 2019). The K2P model and the Tajima's test for pair-wise distance and nucleotide diversity (Tajima, 1989) estimation were conducted in MEGA, respectively. The compositions of nucleotides and the diversity of haplotype were measured using the workbench tools delivered in BOLD. Less than $3 \%$ of the divergence between the unknown and the reference sequence was used to assign a specie level identity (Valdez-Moreno et al., 2012). That is, if the sequence matches reference GenBank sequence by at least $97 \%$, the species identity has been accepted. To estimate the number of species and haplotypes present in the sample, we used the accumulation curve provisions provided in BOLD to visualise the taxonomic and sequence diversity. The also helps the user to monitor and compare the efficacy of sampling between groups or sites.

Sequence data generated in this study was released through GenBank and accessible via accession numbers JX676110-JX676180. Sequences along with their meta-data were also made available via BOLD (www.barcodeoflife.org) and could be accessed via project code DADB, and title; "Dietary analysis using DNA barcodes" or through http://dx.doi.org/10.5883/DS-DADB. 


\section{Results}

\subsection{Morphometric characterization of $A$. maculatus}

This is the first study that explores A. maculatus's gut content that occurr in Indian water using DNA barcodes. Out of 40 A. maculatus sampled, average length of $21.15 \mathrm{~cm}$ and biomass of $130.27 \mathrm{~g}$ was recorded (Table 1). The total length varied from 11 and $30 \mathrm{~cm}$, and biomass ranged between 112 and $151 \mathrm{~g}$. In pre- and post-monsoons sampling, maximum (30 $\mathrm{cm})$ and minimum $(10.3 \mathrm{~cm})$ lengths were recorded, respectively.

Table 1: Mean values and ranges of Arius maculatus total length (Lt) and biomass sampled from the velar estuary

\begin{tabular}{llllll}
\hline Season & No. of guts & Lt $(\mathbf{c m})$ & \multicolumn{3}{l}{ Biomass $(\mathbf{g})$} \\
\cline { 3 - 6 } & & Mean \pm SD & Range & Mean + SD & Range \\
\hline Pre-monsoon & 22 & $22.67 \pm 6.7$ & $11.67-30.6$ & $134.23+14.28$ & $114.56-151.23$ \\
\hline Post-monsoon & 18 & $19.28 \pm 6.13$ & $10.3-27.98$ & $125.44+14.22$ & $112.6-148.78$ \\
\hline Over all & 40 & $21.15 \pm 6.6$ & $11.67-30.6$ & $130.27 \pm 14.75$ & $112.6-151.23$ \\
\hline
\end{tabular}

\subsection{Dietary composition and sequence analysis}

Of the 40 stomach contents examined (22 in pre-monsoon, 18 in post-monsoon), 32 stomachs $(80 \%)$ had prey taxa that could be measured. 6 and 2 individuals collected in premonsoon and post-monsoon did not had measurable prey items, respectively. A total of 76 prey items were collected, of which 67 items were successfully sequenced $(88.15 \%)$. The prey taxa could be classified into 4 major phyla, viz., Chordata, Arthropoda, Annelida and Mollusca. 4 barcodes of $A$. maculatus and 67 prey taxa constituted 71 sequences (DADB1 to DADB71) for BLAST analysis. DADB1 to DADB4 were A. maculatus tissue samples randomly sampled twice each time during pre-and post-monsoon. The pre-monsoon samplings of prey items were tagged from DADB5 to DADB33 $(n=29)$ and the postmonsoon sampling were from DADB34 to DADB71 $(n=38)$. Table S1 list the respective PCR primer pairs (FishF1/FishR1 or LCO1490/HCO2198) used to barcode.

In GenBank database, all 71 sequences were matched with $<3 \%$ cut off with that of reference sequences by identifying the taxa to species level. The prey taxa belonged to 13 species (12 genera in 11 families) under 4 phyla (viz., Chordate, Arthropod, Annelida and Mollusca) (Table S1). Pisces constituted the major prey items (43.28\%) followed by Arthropod (29.85\%), Annelida (17.91\%) and Mollusca (8.95\%). List of Pisces and 
invertebrate species and their seasonal variability was represented in Fig. 1. Of 29 Pisces sequences, 7 species were recognized viz., Eubleekeria splendens, Stolephorus indicus, Photopectoralis bindus, Leptomelanosoma indicum, Lutjanus fulviflamma, Upeneus vittatus, and Gerres filamentosus, respectively. In Annelida (Capitella capitata, Perinereis vallata), Arthropoda (Clibanarius clibanarius, C. longitarsus) and Mollusca (Meretrix meretrix, Perna viridis), the remaining taxa were made up of 2 species each.

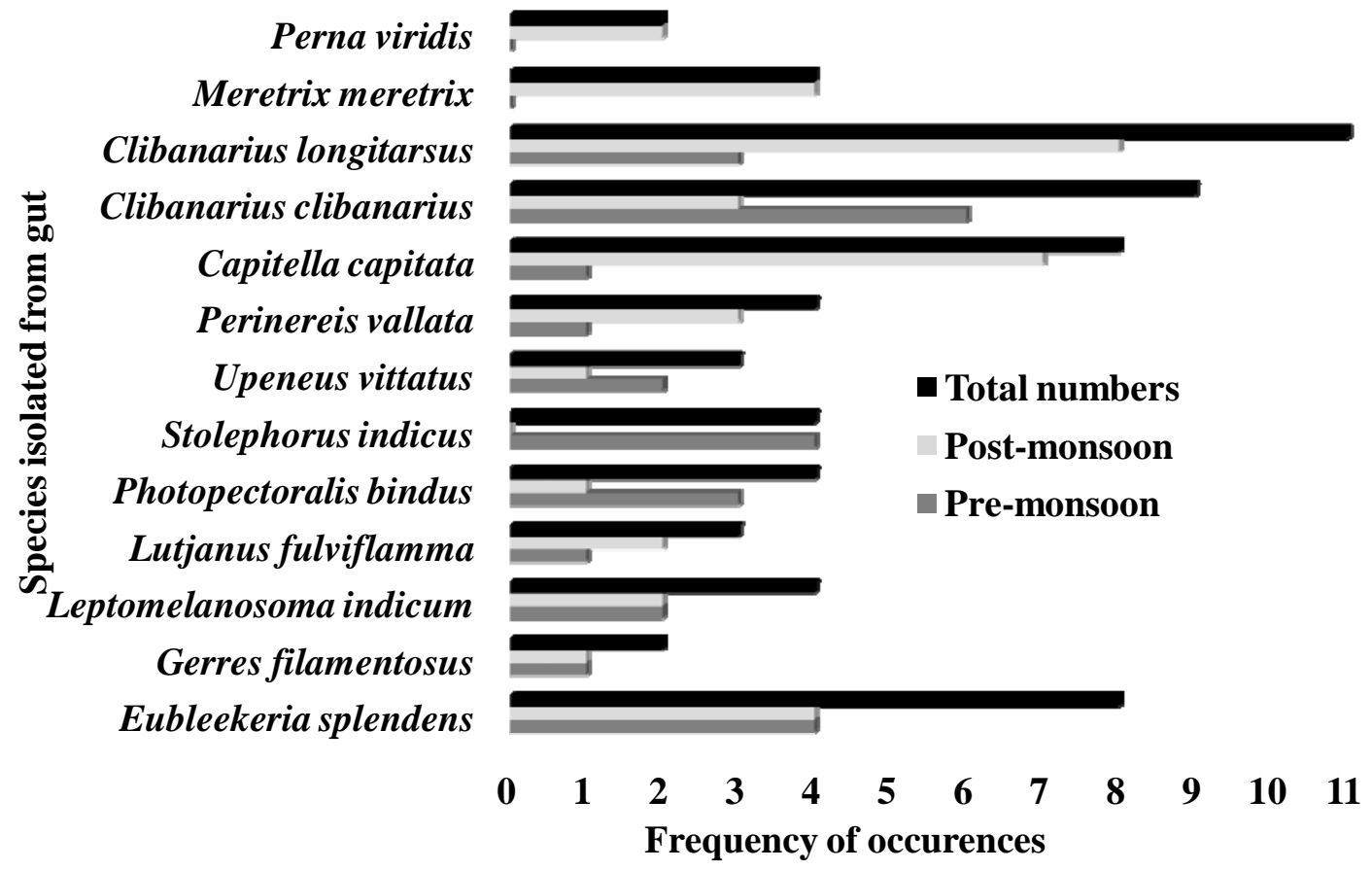

Fig. 1: Seasonal variation in diet diversity of A. maculatus. The isolated species and their frequency of occurrence were given in the $\mathrm{X}$ and $\mathrm{Y}$ axes, respectively.

The mean BLAST similarity score was $98.94 \%$ with standard deviation of $\pm 0.99 \%$ (Table S1). The maximum and minimum similarity scores were respectively $100 \%$ and 97.01\%. All 4 barcodes of $A$. maculatus was precisely identified with $>99.3 \%$ identity (Table S1). All 71 barcodes produced in this study contained $43 \%$ average GC content (in the range of $35-50 \%$ ) (Table 2).

Table 2: Summary statistics for nucleotide frequency distribution of dietary barcodes

\begin{tabular}{lcccc}
\hline Composition (\%) & Minimum & Mean & Maximum & Standard Error \\
\hline Guanine (G) & 16.98 & 19.12 & 22.73 & 0.22 \\
\hline Cytosine (C) & 13.49 & 23.91 & 30.08 & 0.64 \\
\hline Adenine (A) & 19.16 & 24.10 & 29.84 & 0.35 \\
\hline Thymine (T) & 27.76 & 32.87 & 42.68 & 0.59 \\
\hline
\end{tabular}




\begin{tabular}{lllll}
\hline GC & 35.04 & 43.03 & 50.86 & 0.56 \\
\hline GC Codon position 1 & 40.47 & 52.15 & 59.45 & 0.64 \\
\hline GC Codon position 2 & 38.14 & 42.63 & 44.08 & 0.13 \\
\hline GC Codon position 3 & 19.52 & 34.31 & 52.58 & 1.08 \\
\hline
\end{tabular}

\subsection{NJ tree-based species identification}

Identification of $A$. macultus specimens were also verified using the reference sequences extracted from GenBank via NJ tree construction. Other species in the Arius genera, such as A. manillensis (HQ682617), A. dispar (KF604635), A. subrostratus (MK348195), and A. jella (KU894613) was used as an out-group in the construction of $\mathrm{NJ}$ tree. All four sequences (DADB1-DADB4) have been placed in a single clade (Fig. 2). Presence of haplotypes within the 4 COI sequences of $A$. maculatus was also hinted.

For the construction of the $\mathrm{NJ}$ tree, all 7 piscine species with their reference sequences ( 2 to 5 reference sequences per species) constituting a total of 56 nucleotide sequences were used. All pisces prey taxa clustered in one clade with its respective species indicating the similarity between the sequenced COI and sequenced taxa in the database (Fig. 3). Even the cladding patterns of constructed $\mathrm{NJ}$ tree suggested the presence of haplotypes among the prey taxa; for example, 2 sub-clades were evident among the Stolephorus indicus clade (the top most clade of the NJ tree) (Fig. 3). One contained DADB11, DADB12 and DADB24 with other sequences of reference, and another contained DADB26 and DADB30 with other sequences of reference. Similar patterns were also observed in U. vittatus, E. splendens and L. indicum clades. For the NJ tree based invertebrate prey taxa identification, the 2 to 9 reference sequence per invertebrate prey taxa was similarly used. The final dataset had 68 nucleotide sequences. All invertebrate prey taxa in Arthropod, Annelid and Mollusca, clustered with its respective sequences of the reference species in single clade (Fig. S1), indicating the success of tree based identification.

\subsection{Dietary diversity: Pre-monsoon versus Post-monsoon}

The major difference between pre- and post-monsoon dietary composition is that, in premonsoon, the molluscan taxa was completely absent and a piscine species (Stolephorus indicus) was present only in pre-monsoon (Fig. 1). Among piscine taxa, Eubleekeria splendens $(23.5 \%)$ and Stolephorus indicus $(23.5 \%)$ were the major prey taxa followed by Photopectoralis bindus (17.6\%) during pre-monsoon while E. splendens (36.36\%) alone 
forms the major prey taxa followed by Leptomelanosoma indicum (18.18\%) and Lutjanus fulviflamma (18.18\%) during the post-monsoon season.

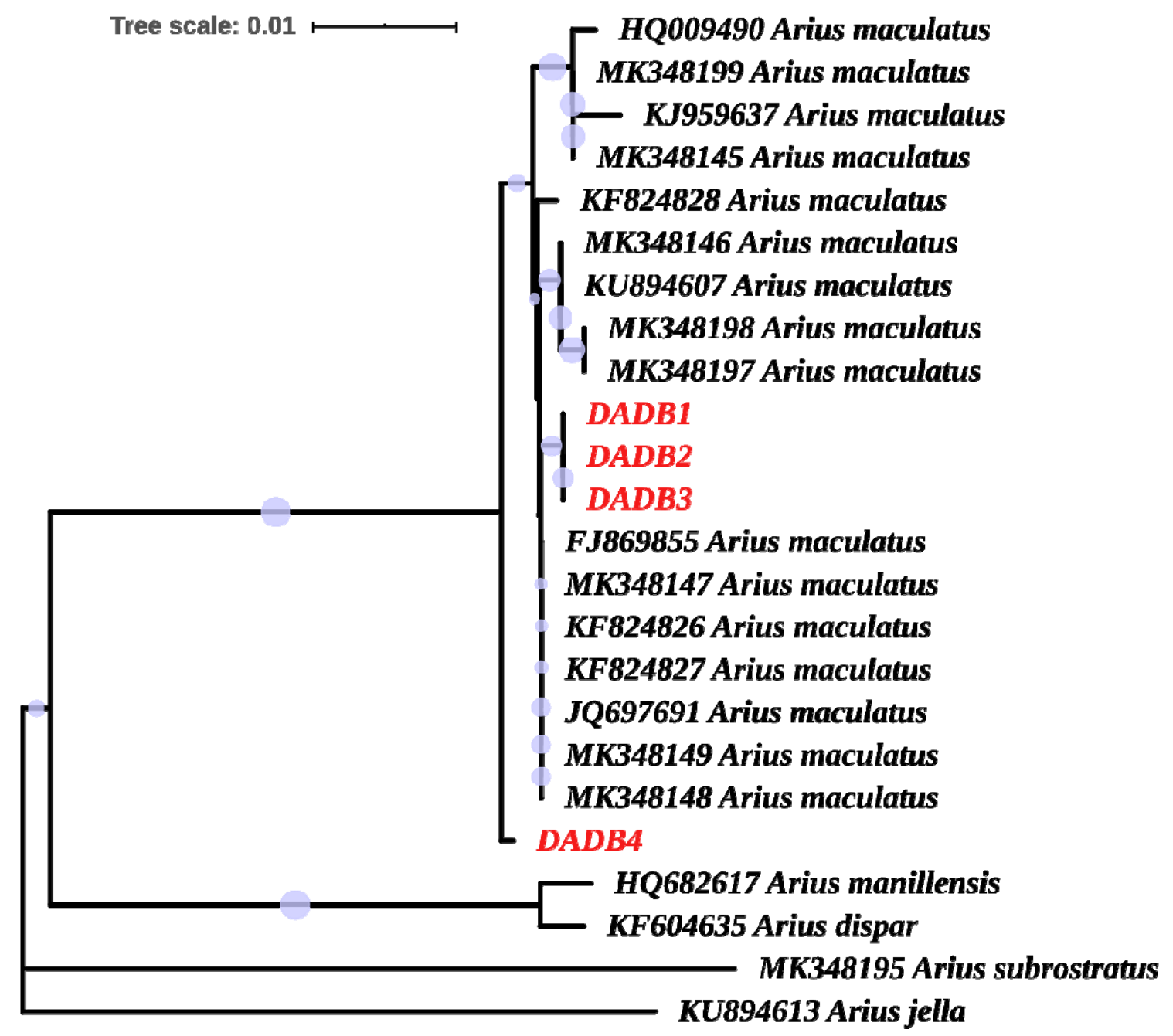

Fig. 2: COI-NJ tree based identification of Arius maculatus. DADB1-DADB4 were the sequences produced in this study. The alpha-numerical present prefix to species name represent the Genbank accession numbers. Different species of Arius genera was used as an out-group was successfully delineated.

The hermit crabs forms the major constituents of both pre- and post-monsoon seasons (81.81\% \& 40.74\%, respectively) among invertebrate taxa. The dominant (54.54\%) invertebrate prey taxa were the hermit crab, Clibanarius clibanarius was followed by $C$. longitarsus (27.27\%) during pre-monsoon sampling. Clibanarius longitarsus were the dominant $(33.33 \%)$ invertebrate prey taxa during post-monsoon sampling followed by a polychaete worm Capitella capitata $(25.92 \%)$ (Fig. 1). 


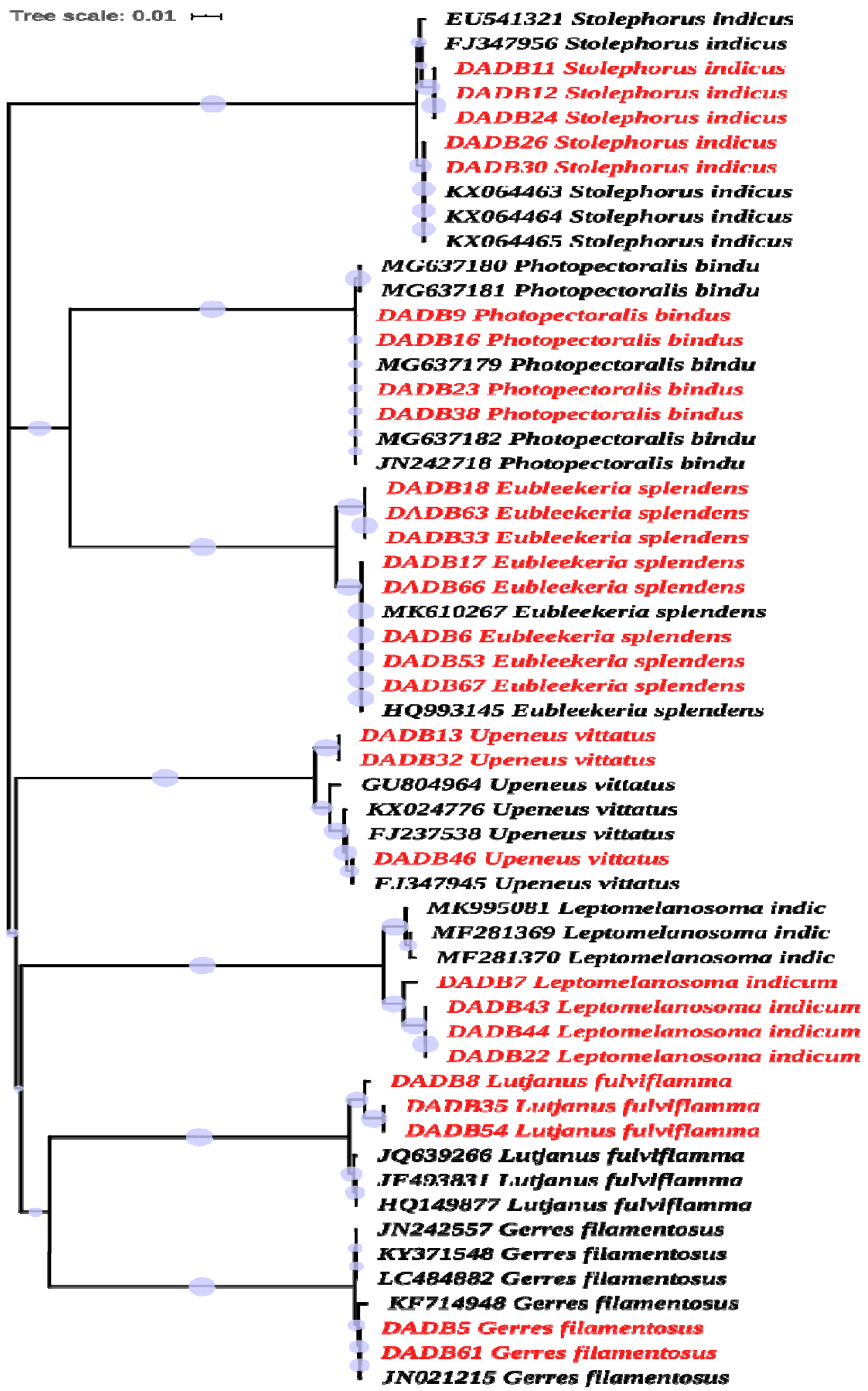

Fig. 3: NJ tree constructed for tree based identification of pisces prey taxa. The percentage of 
replicate trees in which the associated taxa clustered together in the bootstrap test (100 replicates) are shown as circles next to the branches. The number of base substitutions per site was indicated as tree scale given on the top left corner. The acronym DADB and alphanumerical prefix to the species name indicates the sequences produced in this study and reference sequence, respectively.

During pre-monsoon, piscine gut items constituted the major prey taxa (58.62\%) and invertebrate forms the major prey (71.05\%) taxa in post-monsoon season. During the postmonsoon, consumption of piscine items dropped by $20.69 \%$ and invertebrate taxa increased by $42.11 \%$. However, as the sample size was severely limited to draw such inference, it was possible to adjust further sampling efforts accommodated with next generation sequencing to verify such claims.

For invertebrate taxa, the average pair-wise distance (pwd) and nucleotide diversity were higher ( 0.35 and 0.26 , respectively) than for pisces ( 0.22 and 0.18 , respectively) (Table 3). During the post-monsoon season, the total higher pwd values $(0.40)$ were observed than pre-monsoon values (0.31) suggesting higher dietary diversity consumed in the post-monsoon season. Similarly, the decrease in pisces's pwd and nucleotide diversity values and increased values of the same parameters in post-monsoon invertebrate prey taxa indicate that invertebrates were more preferred diet during the post-monsoon season. The overall pwd values for the barcoded prey taxa were 0.377 .

Table 3: Pair-wise distance (Pwd) and nucleotide diversity $(\pi)$ of diet-DNA barcodes

\begin{tabular}{lllllll}
\hline & \multicolumn{2}{l}{ Pre-monsoon } & \multicolumn{2}{l}{ Post-monsoon } & \multicolumn{2}{l}{ Overall } \\
& Pwd & $\pi$ & Pwd & $\pi$ & Pwd & $\pi$ \\
\hline Pisces & 0.223 & 0.187 & 0.124 & 0.180 & 0.221 & 0.184 \\
\hline Invertebrates & 0.206 & 0.164 & 0.386 & 0.282 & 0.346 & 0.257 \\
\hline Overall & 0.314 & 0.246 & 0.405 & 0.299 & 0.377 & 0.283
\end{tabular}

\subsection{Haplotype diversity}

The analysis of the accumulation curve in BOLD reveals the presence of 57 haplotypes within 14 species barcoded (including the host A. maculatus) (Fig. 4). In Pisces (47.36\%), the majority of haplotypes were found, followed by Arthropods (28.07\%), Annelids (14.03\%) and Mollusca (10.52\%). Inthis analysis, the mean haplotype $(n=57)$ richness per taxa barcoded taxa $(n=14)$ was found to be 4.07 . 


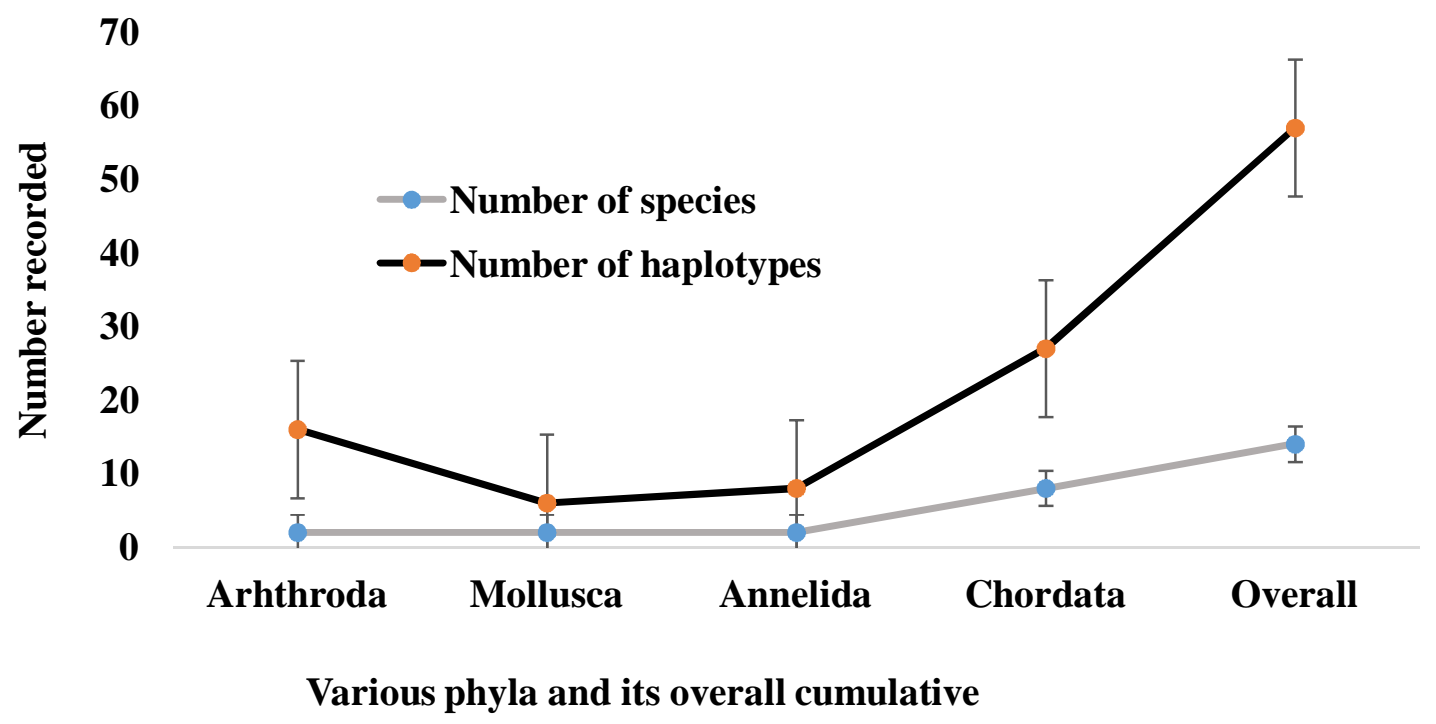

Fig. 4: Accumulation curve demonstrating the documentation of various haplotypes present among the taxa in dietary composition.

\section{Discussion and conclusion}

In this study, the mean length recorded was comparable to A. maculatus occurring on the west coast of India (Maitra et al., 2019), but comparatively smaller than those occurring on the coast of Philippines (Chu et al., 2011). Many studies have not been able to identify the stomach content (prey items) of fishes using conventional morphological analysis (Legler et al. 2010; Paquin et al. 2014; Moran et al. 2015), as the digestive process rapidly disintegrates the morphological characteristics of the prey item (Schooley et al. 2008; Legler et al. 2010; Carreon-Martinez et al. 2011), resulting in substantial losses of the valuable data for taxonomist and resource managers. While in this study, most prey items were in high digestive state and rendered morphological identification impossible, segregating and treating the individual stomach content for DNA barcoding resulted in a success rate of $88 \%$ sequencing with $100 \%$ species level identification. Using visual survey, previous analysis, which could only assign $10 \%$ of catfish gut content to species level, used DNA barcoding to witness the taxonomic assignments to species level identification of $90 \%$ of prey items (Aguilar et al., 2016). None of the specimen could be recognised in this study without DNA barcoding, which could lead to poor understanding of catfish and their diet diversity. Previous nationalised efforts to barcoding the marine diversity (Lakra et al., 2010; Bineesh et al., 2014; Bamaniya et al., 2015) along with localised efforts to barcode the diversity of 
Vellar estuary (Khan et al., 2010, 2011; PrasannaKumar et al., 2012; Thirumaraiselvi et al., 2015; Rajthilak et al., 2015; Rahman et al., 2013, 2019; Hemalatha et al., 2016; Sahu et al., 2016; Palanisamy et al., 2020; PrasannaKumar et al., 2020; Manikantan et al., 2020; Thangaraj et al., 2020; Narra et al., 2020) resulted in strengthening the reference library which insured that no ambiguous sequences were present in this study (as all sequences were identified to species level). Identification success was likely due to the use of previously generated references sequences from Indian waters from morphologically verified species and published through reference databases (such as GenBank and BOLD). This is significant because the ability of DNA barcoding to identify unknown specimens might be impeded by miss-identification of reference specimen, cryptic diversity, sharing of haplotype, and lack of reference sequences (i.e., species yet not barcoded) in the database.

Previously, cryptic diversity has been recorded among catfish prey (April et al., 2011) and Indian waters have vast marine fish diversity (2443 species) (Gopi and Mishra, 2015) with several cryptic families (Bamaniya et al., 2015). The application of DNA barcoding in this study, identified 57 haplotypes in 14 species barcoded. When we previously barcoded Vellar estuarine fishes (43 species), for the first time $58 \%$ ( $n=25$ species) were sequenced (Khan et al., 2011). These first time barcodes have been useful to identify Lutjanus fulviflamma, Stolephorus indicus, Upeneus vittatus, and Eubleekeria splendens in this study. In this study, the wide diversity of marine fish in catfish diets (7 species in 5 families) was not surprising, as previous studies have witnessed 23-25 fish taxa (up to 11 families) in catfish diets (Moron et al., 2015; Aguilar et al., 2016). Previous studies using DNA barcoding to investigate the catfish diet were limited to fish prey items (Moron et al., 2015; Aguilar et al., 2016), considering the difficulties of segregating and sequencing invertebrates. This study is the first of its kind to investigate the diversity of invertebrate prey in the diet of catfish using DNA barcodes. The economically important clams (Meritxix meritrix) (Yeh et al., 2016; Desrita et al., 2019) and mussel (Perna viridis) (Sulvina et al., 2020) found in the diet of A. maculatus in this study is of concern, as local populations were known to depend on these resources for food. Since accurate identification of macro-benthic invertebrates from benthophagous fish could facilitate the assessment of human impact on the ecosystem (Tupinambás et al., 2015), further studies could be directed toward a detailed picture of trophic levels in DNA barcoding based gut analysis of other catfish and fin fish species inhabiting Vellar estuary (Khan et al., 2011; Sakthivel et al., 2012).

We found that in pre-monsoon A. maculatus was more piscivorous than post-monsoon. However such conclusions should be supported by multiple seasonal sampling and not with 
single seasonal sampling like in this study. It was also appropriate to note that most prey items (almost all larvae and immature forms) identified in this study, were of commercially important fish species such as Eubleekeria splendens, which occurred abundantly in the East and West coast of India (Rawat et al., 2019). The diversity of diet estimated through DNA barcoding shows that, A. maculatus can feed at a range of depths and habitats (especially indicated by the high haplotype diversity), including shallow margins (such as mangrove habitats where immature forms seeks habitats) and open waters. The DNA sequencing mechanism and success of the detection of prey items might be disrupted by co-amplificatin of the predator's DNA along with its prey (Vestheim and Jarman 2008; Leray et al. 2015). We have not obtained any co-amplification of A. maculatus, however. Similar observations were also previously made (Carreon-Martinez et al., 2011). While contaminations may have triggered sequencing failures (since approximately $12 \%$ of the samples were not successfully sequenced), false positive detections did not result (as all prey barcodes matched the level of species cut off with that of the same species in the reference database).

We found that DNA barcoding was very effective in the identification of even highly digested prey items. In this and other studies, prey items have been digested to the point that even higher taxonomic ranks of the prey could not be given an indication by the visual exam (Carreon-Martinez et al. 2011; Schloesser et al. 2011; Moran et al. 2015; Rocha et al. 2015; Aguilar et al., 2016). Even though the present study involved the detection of fish and invertebrates through DNA barcoding, the success rates of barcoding were higher than previously reported $\sim 65 \%$ by Moran et al. (2015), $70 \%$ by Cote et al. (2013), $\sim 80 \%$ by Carreon-Martinez et al. (2011) and nearly equivalent to (93\%) Aguilar et al. (2016). The variations in the success rate of barcoding may be due to the choice of sequencing techniques, predator/prey within each study, prey item acquisition, predator/prey handling, and prey condition (digestion resistant features) (Macdonald, 1982; Buckland et al., 2017). Although the DNA barcoding techniques for fish and invertebrate using universal robust primers have been well developed (Ivanova et al. 2007; Weigt et al. 2012, Ward et al., 2005, Prasannakumar et al., 2012, 2020), barcoding success rates may be more likely to be affected during prey acquisition and other upstream barcoding processes (storage, pre-processing, DNA extraction, etc.), as higher success rate was witnessed in processing freshly acquired guts rather than the ethanol preserved whole predator samples. Limited diffusion of preservative medium into gut contents was reported for decrease success rate (ValdezMoreno et al., 2012). In this study, care was taken to process the gut samples as fresh as could and the individual prey items was stored in ethanol rather than the whole predator. We 
also recommend that the extracted gut contents be stored in a deep freezing condition rather than in a preservative medium for a higher success rate of barcoding as previously observed (Aguilar et al., 2016).

We propose estimating the degree of generalist predation among the predators through pair-wise distance (pwd) and nucleotide diversity $(\pi)$ estimation. For example, in postmonsoon in the diet of A. maculatus, the pwd and nucleotide values of prey items increases, indicating more post-monsoon generalist predation than pre-monsoon predation. However, it was beyond the scope of this study to investigate the factors responsible for such a rise. For now, the influence of pwd and $\pi$ values on predator's biology, functioning of predator habitats is unexplored, as more studies may be directed towards it in the near future. These barcode data (along with the associated full diet analysis) will reveal A. maculatus' trophic dynamics in Vellar estuary and provide valuable data for the development of management strategies, particularly in relation to its predation of commercially important fish and invertebrates. Pisces and invertebrates from these ecosystems will continue to be collected and barcoded, as the coverage of species barcodes in the reference database will become more significant as meta- and environmental DNA barcoding is becoming cheaper and more prevalent in fishery surveys (Leray et al. 2013; Miya et al. 2015; Galal-Khallaf et al., 2016; Evans \& Lamberti, 2018).

\section{Acknowledgement}

First author thanks the Department of Science and Technology's INSPIRE Fellowship (IF10431), India and China Postdoctoral Research Foundation's National Postdoctoral fellowship (0050-K83008), China for the financial assistance. The field help rendered my Mr. Karuna is acknowledged. Authors are grateful to anonymous reviewers for improving the quality of this manuscript. 


\section{References}

Aguilar, R., Ogburn, M. B., Driskell, A. C., Weigt, L. A., Groves, M. C., \& Hines, A. H. (2016). Gutsy genetics: identification of digested piscine prey items in the stomach contents of sympatric native and introduced warmwater catfishes via DNA barcoding. Environmental Biology of Fishes, 100(4), 325-336. https://doi.org/10.1007/s10641-016-0523-8

Ajmal Khan S, Prasannakumar C, Lyla P. S., Murugan S (2011) Identifying Marine fin fishes using DNA barcodes. Current Science, vol. 101 (9): 1152-1154.

Al-Bow HA, Al-Hassan JM, Thomson M, Thulesius O, Elkhawad A. 1997. Multiple vasoactive factors in epidermal secretions of the Arabian Gulf catfish, Arius bilineatus (Valenciennes). General Pharmacology 28(5): 737-744.

Altschul SF, Gish W, Miller W, Myers EW, Lipman DJ (1990) Basic local alignment search tool. J Mol Biol 215:403-410

April J, Mayden RL, Hanner RH, Bernatchez L (2011) Genetic calibration of species diversity among NorthAmerica's freshwater fishes. Proc Natl Acad Sci U S A 108(26): 10602-10607

Arroyave J, Stiassny MLJ (2014) DNA barcoding reveals novel insights into pterygophagy and prey selection in distichodontid fishes (Characiformes: Distichodontidae. Ecol Evol 23(4):4534-4542

Ashiq Ur Rahman, M., PrasannaKumar, C., Mohanchander, P., Manikantan, G., Ajmal Khan, S. and Lyla, P.S. (2019) Identification of eggs, larva and adults of Scylla serrata (Forsskal, 1775) using DNA barcodes. Journal of Aquatic Biology \& Fisheries. 7: 24-30.

Baeza JA, Fuentes MS (2013) Exploring phylogenetic informativeness and nuclear copies of mitochondrial DNA (numts) in three commonly used mitochondrial genes: mitochondrial phylogeny of peppermint, cleaner, and semi-terrestrial shrimps (Caridea: Lysmata, Exhippolysmata, and Merguia). Zoo J Linn Soc-Lond 168:699-722

Baker, R., Buckland, A., Sheaves, M., 2014. Fish gut content analysis: robust measures of diet composition. Fish Fish. 15 (1), 170-177. http://dx.doi.org/10.1111/faf.12026

Baker, R., Sheaves, M., (2005). Redefining the piscivore assemblage of shallow estuarine nursery habitats. Mar. Ecol. Prog. Ser. 291, 197-213. http://dx.doi.org/10.3354/meps291197

Baldwin CC, Brito BJ, Smith DG, Weigt LA, Escobar-Briones E (2011) Identification of early life-history stages of Caribbean Apogon (Perciformes: Apogonidae) through DNA barcoding. Zootaxa 3133:1-36 
Bamaniya, D. C., Pavan-Kumar, A., Gireesh-Babu, P., Sharma, N., Reang, D., Krishna, G., \& Lakra, W. S. (2015). DNA barcoding of marine ornamental fishes from India. Mitochondrial DNA Part A, 27(5), 3093-3097. https://doi.org/10.3109/19401736.2014.1003923

Bariche M, Torres M, Smith C, Sayar N, Azzurro E, Baker R, Bernardi G (2015) Red Sea fishes in the Mediterranean Sea: a preliminary investigation of a biological invasion using DNA barcoding. J Biogeogr 42:2363-2373

Barnett A, Redd KS, Frusher SD, Stevens JD, Semmens JM (2010) Non-lethal method to obtain stomach samples from a large marine predator and the use of DNA analysis to improve dietary information. J Exp Mar Biol Ecol 393: 188-192

Beauchamp DA, Wahl DH, Johnson BM (2007) Predator-prey interactions. In: Guy CD, Brown ML (eds) Analysis and interpretation of freshwater fisheries data. American Fisheries Society, Bethesda, Maryland, pp. 765-842

Berg, J., 1979. Discussion of methods of investigating the food of fishes, with reference to a preliminary study of the prey of Gobiusculus flavescens (Gobiidae). Mar. Biol. 50 (3), 263273. http://dx.doi.org/10.1007/bf00394208

Betancur-R R, Broughton RE,Wiley EO, Carpenter K, López JA, Li C, Holcroft NI, Arcila D, Sanciangco M, Cureton II JC, Zhang F, Buser T, Campbell MA, Ballesteros JA, Roa-Varon A, Willis S, Borden WC, Rowley T, Reneau PC, Hough DJ, Lu G, Grande T, Arratia G, Ortí G (2013) The Tree of Life and a New Classification of Bony Fishes. PLoS Curr Tree of Life. Apr 18. Edition 1. doi:10.1371/currents.tol.53ba26640df0ccaee75bb165c8c26288.

Bineesh K.K., Akhilesh K.V., Sajeela K.A., Abdussamad E.M., Gopalakrishnan A., Basheer V.S. and Jena J.K. (2014) DNA Barcoding Confirms the Occurrence Rare Elasmobranchs in the Arabian Sea of Indian EEZ. Middle-East Journal of Scientific Research 19 (9): 12661271.

Boileau N, Cortesi F, Egger B, Muschick M, Indermaur A, Theis A, Büscher HH, Salzburger W (2015) A complex mode of aggressive mimicry in a scale-eating cichlid fish. Biol Lett 11(9):20150521

Braid HE, Deeds J, DeGrasse SL, Wilson JJ, Osborne J, Hanner RH (2012) Preying on commercial fisheries and accumulating paralytic shellfish toxins: a dietary analysis of invasive Dosidicus gigas (Cephalopoda Ommastrephidae) stranded in Pacific Canada. Mar Biol 159:25-31

Buckland, A., Baker, R., Loneragan, N., \& Sheaves, M. (2017). Standardising fish stomach content analysis: The importance of prey condition. Fisheries Research, 196, 126-140. https://doi.org/10.1016/j.fishres.2017.08.003 
Bunholi, I. V., Ferrette, B. L. da S., De Biasi, J. B., Magalhães, C. de O., Rotundo, M. M., Oliveira, C., Foresti, F., \& Mendonça, F. F. (2018). The fishing and illegal trade of the angelshark: DNA barcoding against misleading identifications. Fisheries Research, 206, 193197. https://doi.org/10.1016/j.fishres.2018.05.018

Carreon-Martinez L, Johnson TB, Ludsin SA, Heath DD (2011) Utilization of stomach content DNA to determine diet diversity in piscivorous fishes. J Fish Biol 78:1170-1182

Carvalho, D. C., Guedes, D., da Gloria Trindade, M., Coelho, R. M. S., \& de Lima Araujo, P. H. (2017). Nationwide Brazilian governmental forensic programme reveals seafood mislabelling trends and rates using DNA barcoding. Fisheries Research, 191, 30-35. https://doi.org/10.1016/j.fishres.2017.02.021

Chelsky Budarf A, Burfeind DD, Loh WK, Tibbetts IR (2011) Identification of seagrasses in the gut of amarine herbivorous fish using DNA barcoding and visual inspection. J Fish Biol 79:112-121

Chu. (2011). Estimates of age, growth and mortality of spotted catfish, Arius maculatus (Thunberg, 1792), off the Coast of Yunlin, Southwestern Taiwan. African Journal of Biotechnology, 10(68). https://doi.org/10.5897/ajb11.1552

Conway KW, Baldwin C,White MD (2014) Cryptic diversity and venom glands in western Atlantic clingfishes of the genus Acyrtus (Teleostei: Gobiesocidae). PLoS One 9(5): e97664 Cortés, E., 1997. A critical review of methods of studying fish feeding based on analysis of stomach contents: application to elasmobranch fishes. Can. J. Fish. Aquat. Sci. 54 (3), 726738. http://dx.doi.org/10.1139/f96-316

Cote IM, Green SJ, Morris JA, Akins JL, Steinke D (2013) Diet richness of indo-Pacific lionfish revealed byDNA barcoding. Mar Ecol Prog Ser 472:249-256

Cote L, Johnson TB, Ludsin SA, Heath DD (2011) Utilization of stomach content DNA to determine diet diversity in piscivorous fishes. J Fish Biol 78:1170-1182

Côté, I., Green, S., Morris, J., Jr, Akins, J., \& Steinke, D. (2013). Diet richness of invasive Indo-Pacific lionfish revealed by DNA barcoding. Marine Ecology Progress Series, 472, 249-256. https://doi.org/10.3354/meps09992

Cresson, P., Ruitton, S., Ourgaud, M., \& Harmelin-Vivien, M. (2014). Contrasting perception of fish trophic level from stomach content and stable isotope analyses: A Mediterranean artificial reef experience. Journal of Experimental Marine Biology and Ecology, 452, 54-62. https://doi.org/10.1016/j.jembe.2013.11.014 
Dahl, K. A., Patterson, W. F., III, Robertson, A., \& Ortmann, A. C. (2017). DNA barcoding significantly improves resolution of invasive lionfish diet in the Northern Gulf of Mexico. Biological Invasions, 19(6), 1917-1933. https://doi.org/10.1007/s10530-017-1407-3

Dalton DI, Kotze A (2011) DNA barcoding as a tool for species identification in three forensic wildlife cases in South Africa. Forensic Sci Int 207:e51-e254

Desrita, Susetya, I. E., Suriani, M., \& Rahman, A. (2019). Biology and growth of Asiatic Hard Clam (Meretrix meretrix) population in Tanjung Balai, North Sumatera. IOP Conference Series: Earth and Environmental Science, 260, 012108. https://doi.org/10.1088/1755-1315/260/1/012108

Dhanze J R and Jayaram K C (1982) Some biometric studies of certain closely related species of the genus Arius (Pises: Siluriformes: Ariidea). Proc. Indian Acad. Sci. 91(1): 79-98

Di Pinto, A., Marchetti, P., Mottola, A., Bozzo, G., Bonerba, E., Ceci, E., Bottaro, M., \& Tantillo, G. (2015). Species identification in fish fillet products using DNA barcoding. Fisheries Research, 170, 9-13. https://doi.org/10.1016/j.fishres.2015.05.006

Dunn MR, Szabo A, McVeagh MS, Smith PJ (2010) The diet of deep water sharks and the benefits of using DNA identification of prey. Deep-Sea Res 57:923-930

Ekrem T, Willassen E, Stur E (2007) A comprehensive DNA sequence library is essential for identification with DNA barcodes. Mol Phylogenet Evol 43:530-542

Elliott, J., 1967. The food of trout (Salmo trutta) in a Dartmoor stream. J. Appl. Ecol. 59-71. http://dx.doi.org/10.2307/2401409

Evans, N. T., \& Lamberti, G. A. (2018). Freshwater fisheries assessment using environmental DNA: A primer on the method, its potential, and shortcomings as a conservation tool. Fisheries Research, 197, 60-66. https://doi.org/10.1016/j.fishres.2017.09.013

Felsenstein J. (1985). Confidence limits on phylogenies: An approach using the bootstrap. Evolution 39:783-791.

Folmer O, Hoeh W, Black M, Vrijenhoek R. (1994) Conserved primers for PCR amplification of mitochondrial DNA from different invertebrate phyla. Mol Mar Biol Biotechnol. \3:294-299.

Galal-Khallaf, A., Osman, A. G. M., Carleos, C. E., Garcia-Vazquez, E., \& Borrell, Y. J. (2016). A case study for assessing fish traceability in Egyptian aquafeed formulations using pyrosequencing and metabarcoding. Fisheries Research, 174, 143-150. https://doi.org/10.1016/j.fishres.2015.09.009

Gonçalves PFM, Oliveira-Marques AR, Matsumoto TE, Miyaki CY (2015) DNA Barcoding identifies illegal parrot trade. J Hered 106(S1):560-564 
Gopi, K. C., \& Mishra, S. S. (2015). Diversity of Marine Fish of India. In Marine Faunal Diversity in India (pp. 171-193). Elsevier. https://doi.org/10.1016/b978-0-12-801948$1.00012-4$

Gray, B.P., Norcross, B.L., Blanchard, A.L., Beaudreau, A.H., Seitz, A.C., 2015. Variability in the summer diets of juvenile polar cod (Boreogadus saida) in the northeastern Chukchi and western Beaufort Seas. Polar Biol. 1-12. http://dx.doi.org/10.1007/s00300-015-1796-7

Guillerault, N., Bouletreau, S., Iribar, A., Valentini, A., \& Santoul, F. (2017). Application of DNA metabarcoding on faeces to identify European catfish Silurus glanis diet. Journal of Fish Biology, 90(5), 2214-2219. https://doi.org/10.1111/jfb.13294

Hall, T.A. 1999. BioEdit: a user-friendly biological sequence alignment editor and analysis program for Windows 95/98/NT. Nucl. Acids. Symp. Ser. 41:95-98.

Handy SM, Deeds JR, Ivanova NV, Hebert PDN, Hanner RH, Ormos A, Weigt LA, Moore MM, Yancy HF (2011) A single-laboratory validated method for the generation of DNA barcodes for the identification of fish for regulatory compliance. J AOAC Int 94(1):201-210

Hansson, S., 1998. Methods of studying fish feeding: a comment. Can. J. Fish. Aquat. Sci. 55 (12), 2706-2707. http://dx.doi.org/10.1139/f98-158

Harms-Tuohy, C., Schizas, N., \& Appeldoorn, R. (2016). Use of DNA metabarcoding for stomach content analysis in the invasive lionfish Pterois volitans in Puerto Rico. Marine Ecology Progress Series, 558, 181-191. https://doi.org/10.3354/meps 11738

Hebert PDN, Penton EH, Burns JM, Janzen DH, Hallwachs W (2004) Ten species in one: DNA barcoding reveals cryptic species in the neotropical kipper butterfly Astraptes fulgerator. Proc Natl Acad Sci U S A 101(41):14812-14817

Hellberg, R. S., Isaacs, R. B., \& Hernandez, E. L. (2019). Identification of shark species in commercial products using DNA barcoding. Fisheries Research, 210, 81-88. https://doi.org/10.1016/j.fishres.2018.10.010

Hemalatha, A., Mohammed Esa, S. A. R., Suresh, M., Thajuddin, N., \& Anantharaman, P. (2016). Identification of Odontella aurita by $\mathrm{rbcL}$ gene sequence - a high antibacterial potential centric marine diatom. Mitochondrial DNA Part A, 28(5), 655-661. https://doi.org/10.3109/24701394.2016.1166222

Hernández J. (2019) Feeding studies take guts - critical review and recommendations of methods for stomach contents analysis in fish. J Fish Biol. 95: 1364-1373. https://doi.org/10.1111/jfb.14151 
Holmes, B. H., Steinke, D., \& Ward, R. D. (2009). Identification of shark and ray fins using DNA barcoding. Fisheries 280-288. https://doi.org/10.1016/j.fishres.2008.09.036

Hubert N, Hanner R, Holm E, Mandrak NE Taylor E (2008) Identifying Canadian freshwater fishes through DNA barcodes. PLoS One 3(6): e2490

Hynes, H., 1950. The food of fresh-water sticklebacks (Gasterosteus aculeatus and Pygosteus pungitius), with a review of methods used in studies of the food of fishes. J. Anim. Ecol. 3658. http://dx.doi.org/10.2307/1570.

Hyslop, E., 1980. Stomach contents analysis-a review of methods and their application. J. Fish Biol. 17 (4), 411-429. http://dx.doi.org/10.1111/j.1095-8649.1980.tb02775.x

Ivanova NV, Zemlak TS, Hanner R, Hebert PDN (2007) Universal primer cocktails for fish DNA barcoding. Mol Ecol Notes 7: 544-548.

Jo H, Gim JA, Jeong KS, Kim HS, Joo GJ (2014) Application of DNA barcoding for identification of freshwater carnivorous fish diets: is number of prey items dependent on size class for Micropterus salmoides? Ecol Evol 4:219-229

Joly S, Davies TJ, Bruneau A, Derry A, KembelSW, Peres-Neto P, Vamosi J, Wheeler TA (2014) Ecology in the age of DNA barcoding: the resource, the promise and the challenges ahead. Mol Ecol Resour 14(2):221-232

Jumawan, C., Metillo, E., \& Mutia, M. T. (2020). Stock Assessment of Arius maculatus (Thurnberg, 1792) (Ariidae, Siluriformes) in Panguil Bay, Northwestern Mindanao. The Philippine Journal of Fisheries, 27(1), 40-53. https://doi.org/10.31398/tpjf/27.1.2019a0013

Khan, S. A., Lyla, P. S., John, B. A., Kuamr, C. P., Murugan, S., \& Jalal, K. C. A. (2010). DNA Barcoding of Stolephorus indicus, Stolephorus commersonnii and Terapon jarbua of Parangipettai Coastal Waters. Biotechnology (Faisalabad), 9(3), 373-377. https://doi.org/10.3923/biotech.2010.373.377

Kimura M. (1980). A simple method for estimating evolutionary rate of base substitutions through comparative studies of nucleotide sequences. Journal of Molecular Evolution 16:111120.

Kress WJ, García-Robledo C, Uriarte M, Erickson DL (2015) DNA barcodes for ecology, evolution and conservation. Trends Ecol Evol 30(1):25-35

Kuguru, G., Maduna, S., da Silva, C., Gennari, E., Rhode, C., \& Bester-van der Merwe, A. (2018). DNA barcoding of chondrichthyans in South African fisheries. Fisheries Research, 206, 292-295. https://doi.org/10.1016/j.fishres.2018.05.023 
Kumar S., Stecher G., Li M., Knyaz C., and Tamura K. (2018). MEGA X: Molecular Evolutionary Genetics Analysis across computing platforms. Molecular Biology and Evolution 35:1547-1549.

Lakra, W. S., Verma, M. S., Goswami, M., Lal, K. K., Mohindra, V., Punia, P., Gopalakrishnan, A., Singh, K. V., Ward, R. D., \& Hebert, P. (2010). DNA barcoding Indian marine fishes. Molecular Ecology Resources, 11(1), 60-71. https://doi.org/10.1111/j.17550998.2010.02894.x

Legler ND, Johnson TB, Heath DD, Ludsin S (2010) Water temperature and prey size effects on the rate of digestion of larval and early juvenile fish. Trans Am Fish Soc 139:868-875

Leray M, Knowlton N (2015a) DNA barcoding and metabarcoding of standardized samples reveal patterns of marine benthic diversity. Proc Natl Acad Sci U S A 112(7):2076-2081

Leray M, Meyer CP, Mills SC (2015b) Metabarcoding dietary analysis of coral dwelling predatory fish demonstrates the minor contribution of coral mutualists to their highly partitioned, generalist diet. PeerJ 3: e1047

Leray M, Yang JY, Meyer CP, Mills SC, Agudelo N, Ranwez V, Boehm JT, Machida RJ (2013) A new versatile primer set targeting a short fragment of the mitochondrial COI region for metabarcoding metazoan diversity: application for characterizing coral reef fish gut contents. Front Zool 10:34

Letunic, I., \& Bork, P. (2019). Interactive Tree Of Life (iTOL) v4: recent updates and new developments. Nucleic Acids Research, 47(W1), W256-W259. https://doi.org/10.1093/nar/gkz239

Macdonald, J.S., Waiwood, K.G., Green, R.H., (1982). Rates of digestion of different prey in atlantic cod (Gadus morhua), ocean pout (Macrozoarces americanus), winter flounder (Pseudopleuronectes americanus), and american plaice (Hippoglossoides platessoides). Can. J. Fish. Aquat. Sci. 39 (5), 651-659. http://dx.doi.org/10.1139/f82-094.

Maitra, S., Harikrishnan, M., \& Nidhin, B. (2019). Feeding strategy, dietary overlap and resource partitioning among four mesopredatory catfishes of a tropical estuary. Journal of Fish Biology, 96(1), 130-139. https://doi.org/10.1111/jfb.14194

Manikantan, G., PrasannaKumar, C., Vijaylaxmi, J., Pugazhvendan, S. R., \& Prasanthi, N. (2020). Diversity, phylogeny, and DNA barcoding of brachyuran crabs in artificially created mangrove environments. Cold Spring Harbor Laboratory. https://doi.org/10.1101/2020.09.07.286823 
Mazlan A. G, Abdullah S., Shariman M. G. and Arshad A. (2008) On the Biology and Bioacoustic Characteristic of Spotted Catfish Arius maculatus (Thunberg 1792) from the Malaysian Estuary Research Journal of Fisheries and Hydrobiology, 3(2): 63-70.

Méheust E, Alfonsi E, Le Ménec P, Hassani S, Jung J (2015) DNA barcoding for the identification of soft remains of prey in the stomach contents of grey seals (Halichoerus grypus) and harbour porpoises (Phocoena phocoena. Mar Biol Res 11(4):385-395

Miya M, Sato Y, Fukunaga T, Sado T, Poulsen JY, Sato K, Minamoto T, Yamamoto S, Yamanaka H, Araki H, Kondoh M, IwasakiW(2015)MiFish, a set of universal PCR primers for metabarcoding environmental DNA from fishes: detection of more than 230 subtropical marine species. R Soc Open Sci 2: 150088

Moran Z, Orth DJ, Schmitt JD, Hallerman EM, Aguilar R (2015) Effectiveness of DNA barcoding for identifying piscine prey items in stomach contents of piscivorous catfishes. Environ Biol Fish 99(1):161-167

Moran, Z., Orth, D. J., Schmitt, J. D., Hallerman, E. M., \& Aguilar, R. (2015). Effectiveness of DNA barcoding for identifying piscine prey items in stomach contents of piscivorous catfishes. Environmental Biology of Fishes, 99(1), 161-167. https://doi.org/10.1007/s10641015-0448-7

Nagy ZT, Sonet G, Glaw F, Vences M (2012) First large-scale DNA barcoding assessment of reptiles in the biodiversity hotspot of Madagascar, based on newly designed COI primers. PLoS One 7(3): e34506

Narra, P., Prasannakumar, C., Annadurai, D., \& Mahendran, S. (2020). Identifying seaweeds species of Chlorophyta, Ochrophyta and Rhodophyta using DNA barcodes. Cold Spring Harbor Laboratory. https://doi.org/10.1101/2020.08.30.274456

Nijman, V. (2015). Targeted shark fisheries, DNA barcoding and regulating shark fin trade in Indonesia. Fisheries Research, 168, 33-34. https://doi.org/10.1016/j.fishres.2015.03.016

Osman F, Jaswir I, Khaza-ai H, Hashim R. 2007. Fatty acid profiles of finfish in Langkawi Island, Malaysia. Journal of Oleo Science 56(3): 107-113.

Palanisamy, S. K., PrasannaKumar, C.*, Paramasivam, P., \& Sundaresan, U. (2020). DNA barcoding of horn snail Telescopium telescopium (Linnaeus C, 1758) using mt-COI gene sequences. Regional Studies in Marine Science, 35, 101109. https://doi.org/10.1016/j.rsma.2020.101109

Pappalardo, A. M., \& Ferrito, V. (2015). DNA barcoding species identification unveils mislabeling of processed flatfish products in southern Italy markets. Fisheries Research, 164, 153-158. https://doi.org/10.1016/j.fishres.2014.11.004 
Paquin MM, Buckley TW, Hibpshman RE, Canino MF (2014) DNA-based identification methods of prey fish from stomach contents of 12 species of eastern North Pacific groundfish.Deep-Sea Res 85:110-117

Pinkas, L., 1971. Food habits study. Fish Bull. 152 (5), 10.

PrasannaKumar C, Akbar John B, Ajmal Khan S, Lyla P S, and Jalal K C A (2012) Limit of DNA Barcode in Delineating Penaeus Monodon and in its Developing Stages. Sains Malaysiana 41(12): 1527-1533.

Prasannakumar, C., Manikantan, G., Vijaylaxmi, J., Gunalan, B., Manokaran, S., \& Pugazhvendan, S. R. (2020). Strengthening of marine amphipod DNA barcode libraries for environmental monitoring. Cold Spring Harbor Laboratory. https://doi.org/10.1101/2020.08.26.268896

PrasannaKumar, C., Rethinavelu, S., \& Balamurugan, S. (2020b). First barcodes of Bathynomus kensleyi (Lowry \& Dempsey, 2006) and Bathynomus decemspinosus (Shih, 1972) from the Southeast coast of India. Regional Studies in Marine Science, 101489. https://doi.org/10.1016/j.rsma.2020.101489

Rahman A M, Khan S A, Lyla P S, PrasannaKumar C (2013) DNA Barcoding Resolves Taxonomic Ambiguity in Mugilidae of Parangipettai Waters (Southeast Coast of India). Turkish Journal of Fisheries and Aquatic Sciences 13: 321-330.

Rajthilak, C., Santhanam, P., Raja, M., Suman, T. Y., Rajasree, S. R. R., Ramkumar, R., \& Perumal, P. (2015). First distributional record of Nitokra affinis Gurney, 1927 (Copepoda: Harpacticoida: Ameiridae) from Vellar estuary (south-east India): structural and molecular evidence. Marine Biodiversity Records, 8. https://doi.org/10.1017/s1755267215000391

Ran, K., Li, Q., Qi, L., Li, W., \& Kong, L. (2020). DNA barcoding for identification of marine gastropod species from Hainan island, China. Fisheries Research, 225, 105504. https://doi.org/10.1016/j.fishres.2020.105504

Ratnasingham, S., \& Hebert, P. D. N. (2007). Barcoding: BOLD: The Barcode of Life Data System (http://www.barcodinglife.org). Molecular Ecology Notes, 7(3), 355-364. https://doi.org/10.1111/j.1471-8286.2007.01678.x

Rawat S., Benakappa S., Deepak George Pazhayamadom, Jitendra Kumar, Chitra Soman, Venugopal R. (2019) Stock structure analysis of Splendid ponyfish Eubleekeria splendens (Cuvier, 1829) along Indian coast using truss network system. Indian Journal of Geo Marine Sciences, 48 (04): 434-443.

Ritger, A. L., Fountain, C. T., Bourne, K., Martín-Fernández, J. A., \& Pierotti, M. E. R. (2020). Diet choice in a generalist predator, the invasive lionfish (Pterois volitans/miles). 
Journal of Experimental Marine Biology and Ecology, 524, 151311. https://doi.org/10.1016/j.jembe.2020.151311

Rocha LA, Rocha CR, Baldwin CC, Weigt LA (2015) Invasive lionfish preying on critically endangered reef fish. Coral Reefs 34:803-806.

Rocha, L. A., Rocha, C. R., Baldwin, C. C., Weigt, L. A., \& McField, M. (2015). Invasive lionfish preying on critically endangered reef fish. Coral Reefs, 34(3), 803-806. https://doi.org/10.1007/s00338-015-1293-z

Sahu, S. K., Singh, R., \& Kathiresan, K. (2016). Multi-gene phylogenetic analysis reveals the multiple origin and evolution of mangrove physiological traits through exaptation. Estuarine, Coastal and Shelf Science, 183, 41-51. https://doi.org/10.1016/j.ecss.2016.10.021

Saitou N. and Nei M. (1987). The neighbor-joining method: A new method for reconstructing phylogenetic trees. Molecular Biology and Evolution 4:406-425.

Sakthivel M., Deivasigamani B., Kumaran S., Balamurugan S., Rajasekar T. (2012) Seasonal variation in immune organs and immune response of catfish Arius maculatus in Parangipettai coastal area, J. Chem. Pharm. Res., 4:7: 3342-3348.

Santamaria CA, Locascio J, Greenan TM. 2020. First report of lionfish prey from Western Florida waters as identified by DNA barcoding. PeerJ 8:e9922 https://doi.org/10.7717/peerj.9922

Santos B S and Quilang J P (2011) DNA Barcoding of Arius Species (Siluriformes: Ariidae) in Laguna de Bay, Philippines Using the Cytochrome C Oxidase Subunit I Gene. Philipp. Agri. Scientist, 94(2): 205-210

Saunders, R.J., Fowler, A.J., Gillanders, B.M., 2012. The use of food resources by 0+snapper, Chrysophrys auratus, from northern Spencer Gulf, South Australia. Mar.Freshwater Res. 63 (8), 680-686. http://dx.doi.org/10.1071/MF11266

Schloesser RW, FabrizioMC, Latour RJ, Garman GC, Greenlee B, Groves M, Gartland J (2011) Ecological role of blue catfish in Chesapeake Bay communities and implications for management. In: Michaletz PH, Travnichek VH (ed.) conservation, ecology, and Management of Catfish: the second international symposium. Am Fish Soc Symp 77, Bethesda, Maryland. pp. 369-382.

Schooley JD, Karam AP, Kresner BR, Marsh PC, Pacey CA, Thornbrugh DJ (2008) Detection of larval remains after consumption by fishes. Trans Am Fish Soc 137:1044-1049 Sembiring, A., Pertiwi, N. P. D., Mahardini, A., Wulandari, R., Kurniasih, E. M., Kuncoro, A. W., Cahyani, N. K. D., Anggoro, A. W., Ulfa, M., Madduppa, H., Carpenter, K. E., Barber, P. H., \& Mahardika, G. N. (2015). DNA barcoding reveals targeted fisheries for 
endangered sharks in Indonesia. Fisheries Research, 164, 130-134. https://doi.org/10.1016/j.fishres.2014.11.003

Sharawy, Z. Z., Abbas, E. M., Khafage, A. R., Galal-Khallaf, A., Ismail, R. F., Ahmed, H. O., Mohammed-Geba, K., \& Kato, M. (2017). Descriptive analysis, DNA barcoding and condition index of Penaeids (Crustacea: Decapoda) from the Egyptian Mediterranean coast. Fisheries Research, 188, 6-16. https://doi.org/10.1016/j.fishres.2016.12.007

Sulvina, S., Abidin, Z., \& Supono, S. (2020). Production Analysis of Green Mussel (Perna viridis) in Lampung Province. E-Jurnal Rekayasa Dan Teknologi Budidaya Perairan, 8(2), 975. https://doi.org/10.23960/jrtbp.v8i2.p975-984

Tajima F. (1989). Statistical methods to test for nucleotide mutation hypothesis by DNA polymorphism. Genetics 123:585-595.

Teodoro, S. S. A., Terossi, M., Mantelatto, F. L., \& Costa, R. C. (2016). Discordance in the identification of juvenile pink shrimp ( Farfantepenaeus brasiliensis and F. paulensis $\square$ : Family Penaeidae): An integrative approach using morphology, morphometry and barcoding. Fisheries Research, 183, 244-253. https://doi.org/10.1016/j.fishres.2016.06.009

Thangaraj M, Annadurai D, Ramesh T, Kumaran R \& Ravitchandirane V (2020) DNA barcoding and preliminary phylogenetic analysis of few gastropods (Family: Potamididae and Nassariidae) in Vellar estuary mangroves, India by COI and 18S rRNA genes. Ind. J of Geo. Mar. Sci. 49(4): 596-600.

Thirumaraiselvi, R., Das, S., Ramanadevi, V., \& Thangaraj, M. (2015). MtDNA Barcode Identification of Finfish Larvae from Vellar Estuary, Tamilnadu, India. Notulae Scientia Biologicae, 7(1). https://doi.org/10.15835/nsb.7.1.9478

Thompson,J.D., Gibson,T.J., Plewniak,F., Jeanmougin,F. and Higgins,D.G. (1997) The ClustalX windows interface: flexible strategies for multiple sequence alignment aided by quality analysis tools. Nucleic Acids Research, 25:4876-4882.

Tupinambás, TH., Pompeu, PS., Gandini, CV., Hughes, RM., \& Callisto, M. (2015). Fish stomach contents in benthic macroinvertebrate assemblage assessments. Brazilian Journal of Biology, 75(1), 157-164. https://doi.org/10.1590/1519-6984.09913

Valdez-Moreno M, Quintal-Lizama C, Go’ mez-Lozano R, Garcı́a-Rivas MdC (2012) Monitoring an Alien Invasion: DNA Barcoding and the Identification of Lionfish and Their Prey on Coral Reefs of the Mexican Caribbean. PLoS ONE 7(6): e36636. doi:10.1371/journal.pone.0036636 
Velez-Zuazo, X., Alfaro-Shigueto, J., Mangel, J., Papa, R., \& Agnarsson, I. (2015). What barcode sequencing reveals about the shark fishery in Peru. Fisheries Research, 161, 34-41. https://doi.org/10.1016/j.fishres.2014.06.005

Vestheim H, Jarman SN (2008) Blocking primers to enhance PCR amplification of rare sequences in mixed samples - a case study on prey DNA in Antarctic krill stomachs. Front Zool 5:12

Wang, H.-Y., Dong, C. A., \& Lin, H.-C. (2017). DNA barcoding of fisheries catch to reveal composition and distribution of cutlassfishes along the Taiwan coast. Fisheries Research, 187, 103-109. https://doi.org/10.1016/j.fishres.2016.11.015

Ward RD, Zemlak TS, Innes BH, Last PR, Hebert PDN (2005) DNA barcoding Australia's fish species. Philos Trans R Soc Lond Ser B Biol Sci 360(1462):1847-1857

Ward, R. D., Zemlak, T. S., Innes, B. H., Last, P. R., \& Hebert, P. D. N. (2005). DNA barcoding Australia's fish species. Philosophical Transactions of the Royal Society B: Biological Sciences, 360(1462), 1847-1857. https://doi.org/10.1098/rstb.2005.1716

Weigt LA, Baldwin CC, Driskell A, Smith DG, Ormos A, Reyier EA (2012a) Using DNA barcoding to assess Caribbean reef fish biodiversity: expanding taxonomic and geographic coverage. PLoS One 7(7): e41059

Weigt LA, Driskell AC, Baldwin CC, Ormos A (2012b) DNA barcoding fishes. In: Lopez EricksonDL (ed) DNA barcodes: Methods and Protocols. Humana Press, New York City, NY, pp. 109-126

Wirta HK, Hebert PDN, Kaartinena R, Prosser SW, Várkonyi G, Roslin T (2014) Complementary molecular information changes our perception of food web structure. Proc Natl Acad Sci U S A 111(5):1885-1890

Wong LL, Peatman E, Lu J, Kucuktas H, He S, et al. (2011) DNA Barcoding of Catfish: Species Authentication and Phylogenetic Assessment. PLoS ONE 6(3): e17812. doi:10.1371/journal.pone.0017812

Xu, L., Wang, X., Van Damme, K., Huang, D., Li, Y., Wang, L., Ning, J., \& Du, F. (2021). Assessment of fish diversity in the South China Sea using DNA taxonomy. Fisheries Research, 233, 105771. https://doi.org/10.1016/j.fishres.2020.105771

Yeh, C.-Y., Huang, J.-F., Lee, J.-M., \& Schafferer, C. (2016). An economic analysis of hard clam (Meretrix meretrix) farmer polyculture with milkfish (Chanos chanos), silver sea bream (Rhabdosargus sarba), and shrimps at different hard clam stocking densities: a case study of Yunlin County, Taiwan. Aquaculture International, 25(3), 1039-1055. https://doi.org/10.1007/s10499-016-0094-x 
Zhang, Y.-H., Qin, G., Zhang, H.-X., Wang, X., \& Lin, Q. (2017). DNA barcoding reflects the diversity and variety of brooding traits of fish species in the family Syngnathidae along China's coast. Fisheries

Research,

185 , 137-144.

https://doi.org/10.1016/j.fishres.2016.09.015 